\author{
JoAnna Maria DróżDŻ-Afelt, Beata Koim-Puchowska, Aleksandra MenkA
}

\author{
Uniwersytet Kazimierza Wielkiego \\ Zakład Biotechnologii \\ Księcia Józefa Poniatowskiego 12, 85-671 Bydgoszcz \\ E-mail: jdrozdz@ukw.edu.pl \\ koimpuch@ukw.edu.pl \\ alex.em@ukw.edu.pl
}

\title{
WYBRANE PIERWIASTKI ŚLADOWE W ORGANIZMIE CZŁOWIEKA
}

W żywej materii w mierzalnych ilościach występuje około 50 pierwiastków. U ssaków, w tym ludzi wykazano, że 23 pierwiastki mają udowodnioną aktywność fizjologiczną. Wśród nich 11 sklasyfikowano jako niezbędne pierwiastki śladowe, występujące w ograniczonej ilości w organizmie. Wymienia się wśród nich metale przejściowe: wanad, chrom, mangan, żelazo, kobalt, miedź, cynk i molibden, oraz niemetale: selen, fluor i jod. Wszystkie sa mikroelementami, których wymagana, dostarczana do organizmu ilość mieści się w granicach $100 \mathrm{mg} /$ dzień. Pierwiastki te sa istotnymi komponentami struktur biologicznych, ale do pierwiastków śladowych należą również takie, których obecność w organizmie nie jest konieczna, jak np. ołów, kadm czy rtęć. Tabela 1 zawiera wykaz wybranych pierwiastków śladowych, uwzględniajacy ich podział na pierwiastki niezbędne, częściowo niezbędne, fizjologicznie korzystne oraz takie, których rola fizjologiczna nie została poznana, a może być wręcz niekorzystna (PAIS i BENTON JONES 2000, WILHELM i współaut. 2004, FRAGA 2005).

Światowa Organizacja Zdrowia (WHO) w 1996 r. uznała 19 pierwiastków śladowych za istotne $z$ punktu widzenia zdrowia człowieka i wymienia wśród nich arsen, kadm, nikiel i cynk (NAVARRO SILVERA i ROHAN 2007). Przekroczenie stężeń tych pierwiastków, jak również innych, w tym niezbędnych w organizmie ludzkim, może się wiązać z pojawieniem się wysokiej toksyczności. $Z$ kolei niedobór niezbędnych mikroelementów może być przyczyna zaburzeń procesów fizjologicznych, w których uczestniczą (WILHELM i współaut. 2004, FRAGA 2005). Pierwiastki śladowe występuja powszechnie w środowisku człowieka, a ekspozycja na nie jest zależna od zmiennych pod względem zawartości źródeł, jakimi sa powietrze, woda czy pożywienie. Pierwiastki śladowe moga występować naturalnie w przyrodzie lub sa wprowadzane do środowiska jako produkt działalności człowieka. Duży problem ekologiczny stanowią osady ściekowe, odpady zwierzęce oraz produkty i półprodukty pochodzące $z$ przemysłu, w skład których wchodza znaczne ilości pierwiastków niekorzystnych dla zdrowia człowieka. Ponadto, niektóre naturalne procesy moga być źródłem powstawania znacznej ilości zwiąków toksycznych. Zarówno nadmiar, jak i niedobór pierwiastków śladowych, spowodowany zachwianiem ich dystrybucji w środowisku, moga stać się przyczyną problemów zdrowotnych człowieka (MERIAN 1991, PAIS i BENTON JONES 2000, DARAGo i CHMIELNICKA 2004, LOBINSKI i współaut. 2006).

Substancje chemiczne, w skład których wchodzą pierwiastki śladowe, w różnoraki sposób oddziałuja na organizm człowieka. Decydują o tym ich właściwości fizykochemiczne oraz wiek organizmu, w którym nastapiła ekspozycja, a także okres narażenia. Niektóre pierwiastki moga akumulować się w narzadach i tkankach ze względu na powolny proces wydalania substancji, przy jednoczesnym bardzo szybkim jej wchłanianiu (DARAGo i CHMIELNICKA 2004, NAVARRO SilveRA i ROHAN 2007). 
Tabela 1. Zestawienie wybranych pierwiastków śladowych w zależności od roli biologicznej w organizmie (wg PAIs i Benton Jones 2000, KRZYwy i współaut. 2010).

\begin{tabular}{llll}
\hline Pierwiastki śladowe & & & \\
\hline Niezbędne & Częściowo niezbędne & Korzystne fizjologicznie & Słabo poznana rola biologiczna \\
\hline Mangan (Mn) & Selen (Sn) & Platyna (Pt) & Kadm (Cd) \\
Żelazo (Fe) & Arsen (As) & Złoto (Au) & Rtęć (Hg) \\
Kobalt (Co) & Fluor (F) & Ołów (Pb) \\
Nikiel (Ni) & & \\
Miedź (Cu) & & \\
Cynk $(\mathrm{Zn})$ & & \\
Molibden $(\mathrm{Mo})$ & & \\
Chrom (Cr) & & \\
\hline
\end{tabular}

Obecnie podkreśla się wpływ czynników środowiskowych, właczajac toksyczne pierwiastki śladowe, na występowanie nowotworów. Potwierdzaja to liczne doniesienia o "zawodowym" narażeniu na ksenobiotyki, które moga mieć związek $z$ występowaniem nowotworów, np. pęcherza moczowego czy płuc. Ponadto, wskazuje się też rolę substancji chemicznych zawartych w papierosach, które moga zwiększać podatność na raka płuc. Mechanizmy działania pierwiastków na inicjację procesu nowotworowego nie zostały dokładnie poznane. Kancerogeny chemiczne dzieli się na działajace genotoksycznie i epigenetycznie. Zwiazki genotoksyczne wchodza w bezpośrednia interakcję $z$ DNA, poprzez wiazanie się z kwasami nukleinowymi komórki, wywołujac zmiany w jego strukturze i funkcji lub unieczynniajacc systemy sprawnej naprawy. Kancerogeny epigenetyczne działaja cytotoksycznie, uszkadzaja tkanki, zmieniaja aktywność immunologiczną i hormonalną, zaburzają syntezę DNA czy wytwarzanie reaktywnych form tlenu. Ich wpływ jest zwiazany $z$ dalszymi etapami procesu nowotworowego, poprzez działanie na komórki zmienione lub takie, na które zadziałały wcześniej chemiczne kancerogeny genotoksyczne (DARAGO i CHMIELNICKA 2004, OCIEPA-KUBICKA i OCIEPA 2012).

Ważnym zadaniem medycyny środowiskowej jest biomonitoring ekspozycji na różne zanieczyszczenia substancjami toksycznymi, obejmujacy całe populacje, grupy ludności i poszczególne osoby. Prowadzi się rejestry wartości referencyjnych, które moga wskazywać różnice wynikajace $z$ płci, wieku, palenia papierosów czy konsumpcji alkoholu. Pomiaru stężenia pierwiastków najczęściej dokonuje się w próbach krwi lub moczu (Wilhelm i współaut. 2004, Heitland i KÖSTER 2006). Biomonitoring pierwiastków we krwi osób $z$ nowotworem może pomóc w nakreśleniu mechanizmów zachodzacych w organizmie chorego oraz w ustaleniu powiązań z innymi markerami, np. stresu oksydacyjnego, czy uwarunkowaniami genetycznymi. Znając stężenia konkretnych pierwiastków chemicznych, można porównać wartości ze stężeniami ustalonymi w grupie kontrolnej osób zdrowych i na tej podstawie wyciagnąć wnioski odnośnie aktualnego statusu obciażenia chorego toksycznymi pierwiastkami śladowymi lub wartości niezbędnych mikroelementów.

\section{ŻELAZO}

Żelazo występuje powszechnie w przyrodzie, a jego obecność jest konieczna dla funkcjonowania większości organizmów. Coraz większą uwagę poświęca się jednak zwiazkom metabolizmu tego pierwiastka $z$ procesami nowotworzenia (KUBIAK 2013). U człowieka bierze ono udział w wielu procesach fizjologicznych. Wynika to $z$ faktu, że żelazo, występując w dwóch stanach utlenienia (jony $\mathrm{Fe}^{2+}$ i $\mathrm{Fe}^{3+}$ ), może brać udział w szeregu reakcji, zarówno jako donor, jak i akceptor elektronów (KABATA-PENDIAS i SzTEKE 2004, ARTYM 2008, KUBIAK 2013).

Żelazo w organizmie człowieka ulega przemianom w układzie zamkniętym. Niedobory pierwiastka sa uzupełniane $z$ pożywienia, jednak ilości wchłaniane $z$ przewodu pokarmowego sa niewielkie, a wydalanie żelaza jest również procesem bardzo powolnym. Do krwi $z$ pożywienia wchłania się zaledwie $10 \%$ dostarczonego żelaza i ilość taka jest wystarczajaca dla prawidłowego funkcjonowania organizmu (ARTYM 2008).

Pierwiastek ten w organizmie jest głównie zwiazany $z$ hemoglobina (ok.65\%), mioglobina i różnymi enzymami (ok. 5\%), natomiast pozostałe 20-30\% zmagazynowane jest 
przez ferrytynę i hemosyderynę w wattrobie (ARTYM 2008, KUBIAK 2013). Żelazo wchłonięte w układzie pokarmowym jest transportowane do wszystkich komórek, gdzie, przechodząc przez błonę komórkowa, uczestniczy $\mathrm{w}$ procesach metabolicznych. Możliwy jest w tym obiegu odzysk pierwiastka $z$ rozpadłych czerwonych krwinek i dalsze jego magazynowanie (ARTYM 2008).

Żelazo spełnia w organizmie wiele istotnych funkcji. Uczestniczy w podstawowych procesach metabolicznych, będąc składnikiem wielu enzymów, tj. katalazy, oksydaz, peroksydaz, dehydrogenaz, cytochromów czy reduktazy nukleotydowej. Jony żelaza sa niezbędne w transporcie tlenu i elektronów, syntezie DNA, sa istotne dla aktywności hemoglobiny i mioglobiny, które sa jego transporterami. Wspomagaja także syntezę i katabolizm niektórych hormonów np. tarczycy, aktywność limfocytów, fagocytozę, syntezę kolagenu, unieszkodliwianie RFT i detoksykację ksenobiotyków, np. leków (SUSSMAN 1992, ARTYM 2008).

Zarówno niedobór, jak i nadmiar żelaza sa dla organizmu ludzkiego stanami patologicznymi. Zbyt mało żelaza w diecie prowadzi do niedokrwistości, $z$ kolei przekroczenie niezbędnej ilości może wywołać hemochromatoze lub hemosyderozę. Niezwiazany pierwiastek jest toksyczny, dlatego organizm wykształcił wydajne mechanizmy obronne przeciwko wolnym jonom żelaza. Jest ono wychwytywane przez apotransferynę i w procesach wspomaganych przez ceruloplazminę i transferynę trafia do wnętrza komórki, gdzie jest magazynowane przez ferrytynę i hemosyderynę. Dzięki tym białkom niezwiazane żelazo nie jest kumulowane w organizmie w szkodliwych ilościach (ARTYM 2008).

Wolne żelazo jest inicjatorem reakcji, prowadzacych do powstania reaktywnych form tlenu, które działaja destrukcyjnie na białka, lipidy i DNA komórek. Zmiany wywoływane w kwasach nukleinowych sa szczególnie szkodliwe, gdyż wiąża się ściśle z procesami kancerogenezy. Żelazo bierze udział w reakcji Fentona, której produktem jest wysoce reaktywny rodnik hydroksylowy. Uczestniczy on w ataku na czasteczki DNA, skutkujac tworzeniem 8-okso-dihydro-2'-deoksyguanozyny. Taka zmiana wprowadzona w nici kwasu nukleinowego może prowadzić do mutacji punktowych, zwiększajacc tym samym ryzyko nowotworzenia (SUSSMAN 1992, ARTYM 2008).

Sprawnie działajace mechanizmy obrony antyoksydacyjnej, w tym wydajny metabolizm żelaza jest bardzo istotny w ochronie organizmu przed stresem oksydacyjnym, którego następstwem może być szereg chorób, włączając nowotwory.

\section{CYNK}

Cynk jako mikroelement niezbędny dla funkcjonowania organizmu pełni w nim różnorodne role. Należy jednak mieć na uwadze możliwy negatywny wpływ cynku w przypadku zachwiania jego równowagi. Dlatego wiedza na temat metabolizmu tego pierwiastka $\mathrm{w}$ organizmie i jego oddziaływania na procesy życiowe jest w dalszym ciagu poszerzana (GAPYS i współaut. 2014).

Cynk jest niebiesko-białym metalicznym pierwiastkiem, występujacym naturalnie w skorupie ziemskiej (BROWN i współaut. 2001, KABATA-PEndias i SzTEKE 2004). Do organizmu człowieka, dla którego jest niezbędnym pierwiastkiem śladowym, może trafiać wraz z pożywieniem oraz jako efekt zanieczyszczenia pochodzącego $z$ przemysłu. Duże ilości cynku znajduja się w owocach morza, czerwonym mięsie, orzechach i roślinach straczkowych (BHOwMIK i CHIRANJIB 2010). Z kolei przemysłowym źródłem cynku sa galwanizacja oraz produkcja bomb dymnych, stosowanych przez wojsko (PLUM i współaut. 2010).

Cynk wnika do organizmu droga pokarmowa, wziewną i przez skórę (PLUM i współaut. 2010). Jest adsorbowany w jelicie cienkim i jego wydalanie następuje w największym stopniu również droga pokarmowa (BROwn i współaut. 2001). Pierwiastek kumuluje się głównie w mięśniach i w kościach, większe ilości występują także w prostacie, watrobie, przewodzie pokarmowym, nerkach, płucach czy w mózgu. Transport cynku w organizmie przebiega $z$ udziałem białek surowicy, tj. albuminy, a-mikroglobuliny czy transferryny (PLUM i współaut. 2010).

Cynk, jako jeden $z$ najważniejszych niezbędnych pierwiastków śladowych, jest wymagany dla funkcjonowania ponad 300 enzymów syntezy białka, metabolizmu cukrów, lipidów oraz kwasów nukleinowych. W odróżnieniu od innych jonów metali przejściowych (miedź i żelazo), nie posiada zdolności indukowania uszkodzeń oksydacyjnych w trakcie procesów metabolicznych (DoBRoWOLSKI i współaut. 2000, BROWN i współaut. 2001, CHASAPIS i współaut. 2012].

Mimo wielu istotnych funkcji w organizmie, zarówno niedobór, jak i nadmiar cynku moga wywoływać niekorzystne efekty zdrowotne. Niedobór pierwiastka może być przyczyna zaburzeń w układzie nerwowym, zaniku grasicy, problemów skórnych oraz nieprawidłowości w funkcjonowaniu układu rozrodczego. $Z$ kolei nadmiar cynku może mieć swoje toksyczne efekty, oddziałując na układ oddechowy, nerwowy, pokarmowy i męskie narządy płciowe. Uważa się, że nadmiar tego pierwiastka może stanowić je- 
den $z$ czynników rozwoju raka prostaty. Dotychczas nie ustalono dobrego biomarkera zawartości cynku w organizmie; jako jeden z możliwych podaje się stężenie pierwiastka w osoczu (BROWN i współaut. 2001, PLUM i współaut. 2010).

Wśród potencjalnych mechanizmów toksyczności cynku wymienia się prawdopodobne obniżenie absorpcji miedzi i żelaza, spowodowane wysoka suplementacją cynku. Mechanizmy możliwej kancerogenności cyn$\mathrm{ku}$ stosowanego w wysokich dawkach, nie zostały dokładnie poznane (BROWN i współaut. 2001, PLUM i współaut. 2010].

Cynk $z$ jednej strony jest pierwiastkiem niezbędnym dla funkcjonowania organizmu człowieka, z drugiej, należy mieć na uwadze jego możliwe toksyczne efekty. Zależność tych efektów od dawki, okresu narażenia oraz interakcji $z$ innymi pierwiastkami pozostaja nadal przedmiotem badań.

\section{MIEDŹ}

Homeostaza miedzi jest bardzo ważna dla utrzymania odpowiedniego poziomu metabolizmu człowieka, a jej niedobór lub nadmiar stanowią źródło licznych zaburzeń w funkcjonowaniu organizmu (GUPTA i LUTSENKO 2009). Miedź występuje w środowisku w formie metalicznej oraz jako składnik rud i minerałów. Jest jednym $z$ pierwszych metali używanych przez człowieka, obecnie wykorzystywanym w hydraulice, elektryce i elektronice, w galwanizacji i fotografii, przy produkcji naczyń do gotowania oraz w przemyśle chemicznym (STERN i współaut. 2007, KABATA-PENDIAS i SZTEKE 2012).

Miedź jest pierwiastkiem niezbędnym dla człowieka i jest dostarczana wraz $z$ pożywieniem i woda. Wchłaniana w układzie pokarmowym, wiąże się w krwi $z$ albuminą, glutationem i ceruloplazmina, a wydalana jest z żółcią (DANIEL i współaut. 2004, STERN i współaut. 2007].

Metabolizm miedzi podlega ścisłej kontroli. Białka wiążace miedź odpowiadaja za transport tlenu i elektronów, sa także katalizatorami procesów utleniania i redukcji (DOBROWOLSKI i współaut. 2000). Miedź jest składnikiem wielu enzymów, tj. oksydazy, hydroksylazy, dysmutazay ponadtlenkowej (SOD) oraz oksydazy cytochromowej. Bierze też udział w ekspresji genów, mielinizacji nerwów czy działaniu endorfin (GHAZARYAN 2011).

Miedź, stanowiac niezbedny pierwiastek śladowy, w nadmiarze wykazuje działanie toksyczne, np. na watrobe, kości, układ immunologiczny i system nerwowy. Nadmiar miedzi, poprzez oddziaływanie na metabolizm żelaza, może wywoływać anemię (STERN i współaut. 2007). Jej jony biora także udział w tworzeniu wolnych rodników, przez co moga przyczyniać się do zwiększenia częstości mutacji. Wysokie poziomy miedzi stwierdzono w osoczu krwi pacjentów $\mathrm{Z}$ rakiem płuc, przewodu pokarmowego, mięsakami czy w białaczce (DoBRowolsKI i współaut. 2000).

Dostępne badania nie określiły mechanizmu zmiany stężenia miedzi w chorobie nowotworowej oraz nie ustaliły, czy jest to zjawisko pierwotne, czy następstwo procesu kancerogennego (DOBROWOLSKI i współaut. 2000, GHAZARYAN 2011). Metabolizm miedzi jest istotny $\mathrm{w}$ fizjologii człowieka, gdyż jako pierwiastek niezbędny, w nadmiarze może stać się przyczyną zaburzeń funkcjonowania organizmu.

\section{CHROM}

Chrom jest ważnym pierwiastkiem śladowym niezbędnym dla człowieka, jednocześnie uznawanym za niebezpieczny dla jego zdrowia. Pierwiastek ten był wielokrotnie wiazany ze zwiększeniem ryzyka nowotworów, np. płuc (GUERTIN 2004). Chrom występuje powszechnie w postaci rud, istnieje też szereg źródeł antropogenicznych tego pierwiastka, tj. górnictwo, garbarstwo czy przemysł galwaniczny. Ekspozycja zawodowa występuje przy wydobywaniu rud chromu, w hutnictwie i spawalnictwie (KABATA-PENDIAS 1993, SOBAŃSKI i współaut. 2007).

Chrom dostaje się do organizmu droga pokarmowa, oddechowa i przez skórę. W zależności od stopnia utlenienia, może wykazywać powinowactwo do erytrocytów lub białek osocza, co skutkuje zmienna dystrybucja transportowanych, poszczególnych form chromu. Pierwiastek ten nie podlega kumulacji $\mathrm{w}$ organizmie $\mathrm{i}$ jest wydalany głównie $\mathrm{Z}$ moczem (SOBAŃSKI i współaut. 2007).

Chrom dostarczany w pożywieniu występuje najczęściej na +3 stopniu utlenienia, natomiast chrom na +6 stopniu utlenienia jest uznawany za toksyczny dla czowieka. Zawartość pierwiastka mierzona we krwi wynosi ok. $0.05 \mu \mathrm{mol} \times \mathrm{l}^{-1}$ (TERPIEOWSKA i ZAPOROWSKA 2003, EASTMOND i współaut. 2008).

Uważa się, że chrom pełni rolę w aktywacji receptora insulinowego, tym samym zwiększając wrażliwość komórek na insulinę, może też wykazywać działanie antydepresyjne, co daje nadzieję na wykorzystanie tej wiedzy w poznaniu możliwych metod leczenia takich chorób cywilizacyjnych jak cukrzyca czy depresja (TERPIŁOWSKA i ZAPOROWSKA 2003). Pierwiastek ten wchodzi w skład RNA, prawdopodobnie uczestniczac w stabilizacji jego struktury (SOBAŃSKI i współaut. 2007). 
Z drugiej strony, chrom w nadmiarze jest toksyczny, w efekcie prowadzac nawet do śmierci. Przewlekła ekspozycja na pierwiastek może wywoływać zmiany skórne i narzadowe. Udowodniono w badaniach, że chrom wykazuje działanie mutagenne, a silniej działajacym na DNA jest pierwiastek na +3 stopniu utlenienia. Jednak to pierwiastek na +6 stopniu utlenienia uznany został za zawodowy czynnik rakotwórczy, a chrom $\mathrm{Cr}^{3+}$ nie został zaliczony do związków rakotwórczych, ze względu na brak szczegółowych dowodów (SOBAŃsKI i współaut. 2007).

Znaczenie chromu w metabolizmie człowieka nie zostało jeszcze dokładnie zbadane. Obecnie wiadomo, że pierwiastek ten wpływa na szereg schorzeń, a jego suplementacja jest wymagana w przypadku upośledzonej tolerancji glukozy. Z drugiej strony, wysokie dawki pierwiastka maja efekty toksyczne, a zawodowa ekspozycja na chrom łaczona jest ze zwiększonym ryzykiem nowotworów. Jednocześnie środowiskowe narażenie na pierwiastek nie jest łaczone $z$ efektami kancerogennymi i dla populacji generalnej nie stanowi zagrożenia, poza działaniem uczulajacym (TERPIŁOWsKA i ZAPOROWSKA 2003, SoBAN̂SKI i współaut. 2007).

\section{NIKIEL}

Zauważono, że zawodowe narażenie na zwiąki niklu może zwiększać podatność na występowanie różnych typów nowotworów, np. płuc. Jednocześnie zwraca się uwagę na pozytywna rolę tego pierwiastka w funkcjonowaniu mikroflory jelitowej człowieka, mimo że dokładne mechanizmy nie zostały poznane (GRIMSRUD i współaut. 2003, DAS i współaut. 2008, ZAMBELLI i CIURLI 2013).

Nikiel jest białym metalem o wysokim połysku, występuje w przyrodzie głównie pod postacią tlenków i siarczków. Jest składnikiem minerałów, wydziela się w trakcie wybuchu wulkanów oraz pochodzi ze źródeł antropogenicznych. Pierwiastek ten jest zużywany w wielu procesach przemysłu metalurgicznego, tj. galwanotechnice, wytwarzaniu stopów metali czy produkcji baterii niklowo-kadmowych. Szeroko badana jest dualistyczna natura niklu, który dla ludzi jest zarówno niezbędnym mikroelementem, jak i pierwiastkiem o właściwościach toksycznych (KABATA-PENDIAS 1993, DAS i współaut. 2008, ZAMBELLI i CIURLI 2013).

Nikiel może wnikać do organizmu zarówno w spożywanym pożywieniu i wodzie, wdychanym powietrzu, jak i przez skórę. Z przewodu pokarmowego nikiel jest wchłaniany bardzo słabo, jednak ta droga wprowadzane sa największe liości pierwiastka i jego związków. Ekspozycja na nikiel zawarty w powietrzu jest prawdopodobnie główna przyczyna jego efektów toksycznych. Wartości referencyjne niklu u zdrowej osoby dorosłej wynosza $0,2 \mu g$ x $1^{-1}$ w surowicy. Metabolizm pierwiastka przebiega $z$ wytwarzaniem ligandów i transportem po całym organizmie, m.in. w surowicy krwi. Ligandy te sa krytyczne dla obiegu i przemian pierwiastka, jednak ich rola pozostaje nadal przedmiotem badań. Nieprawidłowa dystrybucja niklu w ustroju człowieka jest wiązana $z$ występowaniem udarów czy zawałów mięśnia sercowego. Nikiel wydalany jest głównie $z$ kałem i moczem (DAs i współaut. 2008).

Uważa się, że nikiel pełni w organizmie rolę co-factora w procesie wchłaniania żelaza w jelitach oraz jest mikroelementem niezbędnym dla prawidłowego funkcjonowania mikroflory jelitowej (DAS i współaut. 2008, ZAMBELLI i CIURLI 2013). Jednak nikiel został uznany przez Międzynarodowa Agencję Badań nad Rakiem (ang. International Agency for Research on Cancer, IARC) za ludzki kancerogen. Świadczą o tym wyniki badań $z$ udziałem modeli zwierzęcych oraz pracowników eksponowanych zawodowo na ten czynnik (RoMANOWICZ-MAKOWSKA i współaut. 2011). Wysokie stężenia niklu stwierdzono u osób zawodowo narażonych na kontakt droga inhalacyjna, a badania $z$ udziałem hutników, pracowników rafinerii i górników wydobywajacych nikiel wykazały zwiększona podatność tych grup na nowotwory (ZAMBELLI i CIURLI 2013).

W zależności od drogi wchłaniania, nikiel może oddziaływać na zdrowie człowieka genotoksycznie, hematotoksycznie, immunotoksycznie, neurotoksycznie, może zaburzać płodność, indukować choroby układu oddechowego i wspomagać procesy kancerogenezy. Zwiazki niklu, stanowiac potencjalny kancerogen, moga indukować transformację nowotworowa komórek. Wyniki dostępnych badań (DAS i współaut. 2008) sugeruja, że kancerogenność niklu może wynikać $z$ wpływu na czynniki genetyczne lub epigenetyczne, bądź współdziałania obu wymienionych. Epigenetyczne efekty niklu sa wywoływane np. poprzez produkcję wolnych rodników. Pierwiastek ma zdolność wiąania się $z$ enzymami naprawy DNA i generowania reaktywnych form tlenu, prowadzac do wyczerpywania glutationu, czego wynikiem moga być zmiany w kwasach nukleinowych, skutkujące mutacjami w aktywnych genach, co jest krytycznym punktem procesu kancerogenezy. W dalszych etapach, na skutek zmian w komórkach, moga rozwijać się procesy nowotworowe (DAS i współaut. 2008). Wiele badań wskazuje na rolę niklu w zwiększaniu podatności na takie nowotwory jak: mięsaki krtani, rak nerek, prostaty czy 
żołądka. Dane jednak nie sa jednoznaczne i mechanizmy toksyczności niklu wymagają dalszych badań (ROMANOWICZ-MAKOWSKA i współaut. 2011).

Majac na uwadze rozpowszechnienie pierwiastka w środowisku człowieka, związki niklu sa istotne dla medycyny środowiskowej i możliwości przeciwdziałania chorobom wywoływanym przez jego toksyczne efekty.

\section{ARSEN}

Udowodniono, że narażenie na związki arsenu wiąże się ze zwiększonym ryzykiem pewnych nowotworów, mimo że dokładne mechanizmy kancerogenności pierwiastka nie zostały poznane. Ciekawym aspektem działania pierwiastka na organizmy może być określenie udziału polimorfizmu genów w osobniczej wrażliwości na ekspozycję na arsen (SZYMAŃSKA-CHABOWSKA i współaut. 2004).

Arsen jest kruchym metaloidem, który występuje powszechnie w skorupie ziemskiej, będąc składnikiem ponad 245 minerałów. Zwiazki arsenu (tlenki arsenu, kwas arsenowy i jego sole) występuja w wielu stopach metali, środkach ochrony roślin, preparatach do konserwacji drewna i skóry, sa stosowane przy wytwarzaniu szkła opalizującego i emalii oraz sa składnikiem leków. Na podstawie badań epidemiologicznych Międzynarodowa Agencja Badań nad Rakiem uznała pierwiastek i jego zwiazki za rakotwórcze, klasyfikujacc je do grupy 1. czynników kancerogennych dla ludzi (KABATA-PENDIAS i SZTEKE 1994, GAWĘDA 2005, GUHA MuZUMDER 2008].

Ekspozycja na arsen następuje droga pokarmowa i oddechową. W skali ogólnoświatowej najwięcej efektow toksycznych wywołuje skażona woda. Warto jednak podkreślić, że w wielu krajach rozwiniętych zmniejsza się sukcesywnie dopuszczalne stężenia tego pierwiastka w wodzie pitnej (KAPAJ i współaut. 2006, GUHA MUZUMDER 2008). W warunkach ekspozycji zawodowej, arsen wchłania się głównie droga oddechowa (GAWĘDA 2005).

Chroniczne narażenie na zwiąki arsenu może powodować choroby skóry, przewlekłe choroby płuc, zmiany w watrobie, nadciśnienie, chorobę niedokrwienna serca, cukrzyce i anemię. Nowotworami zwiąanymi $z$ toksycznościa arsenu sa rak skóry, płuc czy pęcherza moczowego (KAPAJ i współaut. 2006, GuHA MuZuMder 2008).

Mechanizmy toksyczności i szlaki kancerogenezy wywołane arsenem nie zostały jak dotąd wyjaśnione. Zwraca się uwagę na możliwość wywoływania aberracji chromosomowych, indukowania stresu oksydacyjne- go, upośledzenia procesów naprawy i metylacji DNA, zaburzeń czynników wzrostu, proliferacji komórkowej, amplifikacji genów czy supresji genu p53, którego zadaniem jest utrzymanie stabilności genomu (KAPAJ i współaut. 2006).

W celu ochrony zdrowia zalecany jest biomonitoring arsenu w spożywanej wodzie i w organizmie człowieka. Pomiar stężenia pierwiastka powinien obejmować jego łączne ilości w moczu, krwi, paznokciach czy włosach (KAPAJ i współaut. 2006).

\section{RTEĆ}

Rola rtęci w zwiększaniu ryzyka nowotworów nie została dokładnie określona, mimo powiązania efektów pierwiastka $z$ występowaniem nowotworów płuc u ludzi i gruczolakoraków u zwierząt doświadczalnych. Jako prawdopodobny ludzki kancerogen wymieniana jest metylortęć; wpływ metalicznej i nieorganicznej formy pierwiastka wymaga dalszych badań (KAZANTzIS 2002).

Rtęć należy do metali ciężkich, w warunkach naturalnych występuje w ciekłym stanie skupienia i charakteryzuje się duża lotnościa. Pierwiastek ten jest rozpuszczalny w tłuszczach, co ułatwia przenikalność przez błony biologiczne (KABATA-PENDIAS i ŻMUDZKI 1992, CYRAN 2013).

Rtęć występuje w środowisku także w postaci gazów wydobywających się ze skorupy ziemskiej, jednak znaczaca część emisji jest efektem działalności człowieka (ZAHIR i współaut. 2005). Głównym źródłem zanieczyszczeń sa elektrownie węglowe, przemysł chloro-alkaliczny, zakłady produkcji tworzyw sztucznych, pestycydów, spalarnie odpadów miejskich i medycznych, produkcja wapna, wydobycie złota czy amalgamaty stomatologiczne i termometry rtecciowe (HYMAN 2004, ZAHIR i współaut. 2005, CYRAN 2013).

Ekspozycja na sole rtęci najczęściej następuje droga pokarmowa, natomiast bardziej lotne pary metalicznej rtęci moga wnikać do organizmu drogą wziewną. Eliminacja pierwiastka następuje poprzez układ wydalniczy, w zwiazku $z$ czym to nerki sa narządem najbardziej narażonym na kumulację, a przewlekłe zatrucia rtęcia moga prowadzić do ich uszkodzenia. Pierwiastek działa także toksycznie na układ sercowo-naczyniowy, oddechowy, nerwowy, endokrynny oraz na pracę wattroby (CYRAN 2013).

Związki między narażeniem na rtęć a efektem kancerogennym sa nadal niejasne. Uważa się, że zwiąki rtęci moga działać genotoksycznie na komórki człowieka. Wśród molekularnych mechanizmów tego procesu wymienia się indukcje stresu oksydacyjnego, działanie na mikrotubule, zaburzenia me- 
chanizmów naprawy DNA oraz bezpośrednie oddziaływanie na kwasy nukleinowe (CRESPO-LOPEZ i współaut. 2009).

$\mathrm{Z}$ toksykologicznego punktu widzenia, dobrym wskaźnikiem pochłoniętej dawki rtęci jest pomiar stężenia pierwiastka we krwi. Zwiazki rtęci wiąża się $z$ hemoglobina, wobec czego krew obwodowa stanowi istotny biomarker bieżącego narażenia. Jako kolejny marker ekspozycji wymienia się włosy (BuDTZ-JORGENSEN i współaut. 2004).

Działanie toksyczne rtęci poznano w znacznym stopniu, jednak nadal nie sprecyzowano dokładnych mechanizmów działania pierwiastka oraz jego związków $z$ kancerogennością. Zauważono jednak wagę proble$\mathrm{mu}$ dotyczacego zanieczyszczenia powietrza, pożywienia i wody, wprowadzajac kolejne ograniczenia jego emisji.

\section{KADM}

Kadm jest uznawany za pierwiastek kancerogenny, a ekspozycja na jego związi jest wiazana $z$ występowaniem licznych nowotworów, np. raka prostaty. Niejasny mechanizm działania pierwiastka jest przedmiotem badań, próbujacych określić jego rolę w procesach nowotworzenia (ROMANOWICZ-MAKOWSKA i współaut. 2011).

Kadm jest metalem ciężkim, naturalnie wystepujacym w przyrodzie m.in. w rudach zawierających również cynk, miedź i ołów, a także w wyziewach wulkanicznych. W przemyśle jest stosowany jako stabilizator wyrobów z PVC, pigment $\mathrm{w}$ koloryzacji, absorber w elektrowniach jacdrowych, składnik nawozów oraz w produkcji baterii niklowo-kadmowych (GODT i współaut. 2006). Międzynarodowa Agencja Badań nad Rakiem sklasyfikowała kadm jako ludzki kancerogen (RoMANOWICZ-MAKOWSKA i współaut. 2011).

Kadm może dostawać się do organizm droga pokarmowa, oddechowa i przez skórę (GODT i współaut. 2006). Tylko 5\% pierwiastka wprowadzonego $z$ pożywieniem jest wchłaniane w przewodzie pokarmowym, $z$ kolei w płucach jest absorbowane ponad 90\% wdychanego kadmu (RoMANOwICZ-MAKOWSKA i współaut. 2011).

Po przedostaniu się do krwi, kadm wiąże się $z$ białkami i tą droga wędruje do różnych organow. W watrobie indukuje powstawanie metalotioneiny, w przewodzie żółciowym wiąże się $z$ glutationem, może również docierać do jelita cienkiego. W długoterminowej ekspozycji kadm kumuluje się głównie w nerkach (GODT i współaut. 2006, CzECZOT i SKRZYCKI 2015).

Markerem bieżącej ekspozycji na kadm jest stężenie we krwi. U osób niepalących srednia koncentracja pierwiastka we krwi wynosi $0,5 \mu g \times 1^{-1}$. Długoterminowa ekspozycja na kadm jest badana poprzez określanie jego stężenia w moczu (GODT i współaut. 2006).

Wśród efektów biologicznych kadmu, za jeden $z$ głównych uznaje się związek $z$ powstawaniem nowotworów. Badania wskazuja na rolę tego metalu w etiologii nowotworów nerek, watroby, krwi, pęcherza moczowego czy żołądka. Istnieja także dane wskazujace na zwiazek kadmu $z$ indukowaniem raka prostaty, trzustki czy piersi (ROMANOWICZ-MAKOWSKA i współaut. 2011).

Mechanizm kancerogenezy indukowanej kadmem nie został jak dotad dokładnie opisany. Uważa się, że znaczenie moga mieć takie procesy jak regulacja sygnalizacji mitogennej, zaburzenia szlaków naprawy DNA, nabywanie oporności apoptotycznej komórek czy podstawianie kadmu w miejsce cynku w białkach transkrypcyjno-regulatorowych (GODT i współaut. 2006).

W celu ochrony ludzkiego zdrowia należy rozważyć szereg działań dążących do redukcji emisji kadmu, stosując m.in. monitoring środowiskowy.

\section{OŁóW}

W ostatnim czasie szeroko analizuje się wpływ ołowiu na organizm człowieka, majac na uwadze również jego związek $z$ wywoływaniem mutacji chromosomowych. Szczególną uwage zwraca się na ekspozycję zawodową na ołów i badanie możliwych następstw długotrwałego narażenia na jego zwiąki (KRZYWY i współaut. 2010).

Ołów jest metalem ciężkim, szeroko rozpowszechnionym w przyrodzie. W dawnych czasach był szeroko stosowany przez człowieka, obecnie podkreśla się jego niekorzystny wpływ na zdrowie. Pierwiastek uznaje się na możliwy czynnik kancerogenny dla ludzi (KABATA-PENDIAS i SzTEKE 1998, JEMAL i współaut. 2002, KRZYWY i współaut. 2010).

Ołów występuje w powietrzu atmosferycznym i tą droga, w postaci pyłów, może przenikać do dróg oddechowych człowieka. Duże ich stężenie w powietrzu jest związane $z$ hutnictwem i górnictwem; w warunkach naturalnych pierwiastek jest składnikiem pyłów wulkanicznych. Ołów może także zanieczyszczać wodę, będąc składnikiem ścieków przemysłowych i rolniczych. Największe stężenia spotykane są w glebie, ze względu na jego udział w tworzeniu minerałów i występowanie w postaci rud. Zanieczyszczenia pochodzą głównie $z$ przemysłu kopalnianego, przetwórstwa metali oraz sa skutkiem znacznego rozwoju motoryzacji. Z gleb pierwiastek może przedostawać się do roślin, a więc do pożywienia i w łańcuchu troficznym 
dostawać się do organizmu człowieka (KRZYWY i współaut. 2010).

Ołów przedostający się do organizmu poprzez układ oddechowy, pokarmowy lub w małych ilościach przez skórę wiaże się z erytrocytami i ta droga przenoszony jest do organów i tkanek, w których może się kumulować. Pierwiastek może zwiazać sie szybkowymiennie (w krwi i tkankach miękkich) oraz wolnowymiennie (w kościach). Wydalanie następuje $z$ moczem, kałem, potem oraz z mlekiem kobiecym. Najlepszy biomarker bieżącego narażenia na ołów stanowi krew obwodowa, a normy ustalone dla dorosłych

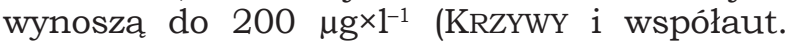
2010).

Uważa się, że ołów ma wysoce niekorzystny wpływ na zdrowie człowieka, oddziałując na układ immunologiczny, moczowy, nerwowy, sercowo-naczyniowy oraz biorac udział $\mathrm{w}$ procesach mutagenezy. Mechanizmy kancerogenności nie zostały dotychczas poznane, sugeruje się jednak, że powoduje zaburzenia syntezy i naprawy jadrowego DNA (JEMAL i współaut. 2002, KRZYwY i współaut. 2010). Nie określono także jednoznacznie typów nowotworów zależnych od wysokich dawek ołowiu, a jako potencjalnych kandydatów wymienia się nowotwory płuc, raka żołądka i glejaki (JEMAL i współaut. 2002, KRZYWY i współaut. 2010).

Powszechnie uważa się, że ograniczenie ilości ołowiu w powietrzu, wodzie i pożywieniu jest istotne dla zdrowia człowieka. Konieczne jest także zabezpieczenie ludzi narażonych na jego wpływ w miejscu pracy.

Opis wymienionych pierwiastków śladowych stanowi zarys możliwych efektów przekroczenia dopuszczalnych stężeń w organizmie człowieka oraz wskazuje na potrzebę monitoringu obiegu substancji chemicznych $\mathrm{w}$ środowisku. W dobie rozwoju nowych technologii, szeroko pojętej industrializacji, ale też występowania określonych zjawisk przyrodniczych (wybuchy wulkanów, powodzie i pożary), kontakt człowieka $z$ pierwiastkami, które naturalnie występuja w małych ilościach w otoczeniu, może nieść poważne konsekwencje dla jego zdrowia i jakości życia. Działania dotyczace ograniczeń emisji substancji mających możliwe działanie kancerogenne oraz badania szlaków metabolizmu pierwiastków niebezpiecznych dla organizmów żywych powinny być podjęte jak najszybciej.

\section{Streszczenie}

W literaturze omawiajacej żywienie człowieka termin „pierwiastki śladowe” dotyczy tych pierwiastków, które w tkankach organizmu występuja w bardzo małych ilościach, bez względu na to, czy sa to pierwiastki niezbędne czy nie. Inaczej rzecz ujmujac, będa to pierwiastki chemiczne, które sa obecne w organizmie lub wymagane dla jego odpowiedniego funkcjonowania, a charakteryzuje je przede wszystkim niewielkie stężenie. W niniejszej pracy omówiono szereg pierwiastków, które w nadmiarze moga stanowić przyczynę zaburzeń w funkcjonowaniu wielu procesów życiowych. Wybrano żelazo, cynk, miedź, chrom, nikiel, arsen, rtęć, kadm i ołów, dla zobrazowania możliwej roli pierwiastków śladowych $\mathrm{w}$ powstawaniu chorób, w tym nowotworów.

\section{LITERATURA}

ARTYM J., 2008. The role of lactoferrin in the iron metabolism. Post. Hig. Med. Dosw. 62, 599611.

Bhowmik D., ChIRANJIB K. P., 2010. A potential medicinal importance of zinc in human health and chronic. Int. J. Pharm. 1, 5-11.

Brown K. H., Wuehler S. E., PEerson J. M., 2001. The importance of zinc in human nutrition and estimation of the global prevalence of zinc deficiency. Food Nutr. Bull. 2, 113-125.

BUDTZ-JORGENSEN E., GRANDJEAN P., JORGENSEN P. J., WeIHE P., KeIDING N., 2004. Association between mercury concentration in blood and hair in methylmercury-exposed subjects at different ages. Environ. Res. 95, 385-393.

ChasAPIS C. T., LOUTSIDOU A. C., SPILIOPOUlOU C. A., Stefanidou M. E., 2012. Zinc and human health: an update. Arch. Toxicol. 86, 521-534.

Crespo-Lopez M. E., Macedo G. L., Pereira S. I. D., ARRifano G. P. F., PiCANCO-Diniz D. L. W., NAscimento J. L. M., Herculano A. M., 2009. Mercury and human genotoxicity: Critical considerations and possible molecular mechanisms. Pharmac. Res. 60, 212-220.

CYRAN M., 2013. Effects of environmental exposure to mercury of the functioning of the human body. Med. Srod. 3, 55-58.

CZECZOT H., SKRZYCKI M., 2015. Kadm-pierwiastek calkowicie zbedny dla organizmu. Cadmium-element completely unnecessary for the or ganism. Post. Hig. Med. Dosw. 64, 38-49.

Daniel K. G., HaRbach R. H., Guida W. C., Dou Q. P., 2004. Copper storage diseases: Menkes, Wilsons, and cancer. Front. Biosci., 26522662.

DARAGO A., ChMIElNiCKA J., 2004. Znaczenie kad$m u$, selenu, cynku $i$ miedzi $w$ rozwoju nowotworów gruczołu krokowego. Nowotwory 54, 384-398.

DAS K. K., DAS S. N., Dhundasi S. A., 2008. Nickel, its adverse health effects \& oxidative stress. Indian J. Med. Res. 128, 412-425.

Dobrowolski Z., DREWNiAK T., CICHOCKI T., KWIATEK W., 2000. Stężenie miedzi i cynku oraz wspótczynnik $\mathrm{Cu} / \mathrm{Zn}$ w surowicy krwi oraz tkance raka jasnokomórkowego nerki. Urol. Pol. 53, 51-63.

EAstmond D. A., Macgregor J. T., Slesinski R. S., 2008. Trivalent chromium: assessing the genotoxic risk of an essential trace element and widely used human and animal nutritional supplement. Crit. Rev. Toxicol. 38, 173190.

FRAGA C. G., 2005. Relevance, essentiality and toxicity of trace elements in human health. Mol. Aspects Med. 26, 235-244.

GAPYS B., RASZEJA-SPECHT A., BIELARCZYK H., 2014. Role of zinc in phisiological and pathological processes of the body. Diagn. Lab. 50, $45-52$.

GAWĘDA E., 2005. Arsen i jego zwiąki w środowisku pracy - zagrożenia, ocena narażenia. Bezpieczeństwo Pracy 3, 26-28. 
GHAZARYAN S., 2011. Role of copper for human organism. Aerospace Med. Human Perform. J. 2, 4-13.

GodT J., Scheidig F., Grosse-Siestrup C., Esche V., BRANDENBURG P., REICH A., GRONEBERG D. A., 2006. The toxicity of cadmium and resulting hazards for human health. J. Occup. Med. Toxicol. 1, 22.

GrimsRud T. K., BERGE S. R., MARTINSEN J. I., ANDERSEN A., 2003. Lung cancer incidence among Norwegian nickel-refinery workers 1953-2000. J. Environ. Monitor. 5, 190-197.

GUERTIN J., 2004. Toxicity and health effects of chromium (all oxidation states). CRC Press LLC, 214-215

GuHA Muzumder D. N., 2008. Chronic arsenic toxicity \& human health. Indian J. Med. Res. $128,436-447$.

GUPTA A., LUTSENKO S., 2009. Human copper transporters: mechanism, role in human diseases and therapeutic potential. Fut. Med. Chem. 1, 1125-1142.

He Z. L., YANG X. E., STOFfella P. J., 2005. Trace elements in agroecosystems and impacts on the environment. J. Trace Elem. Med. Biol. 19, 125-140.

HEITland P., KÖSTER H. D., 2006. Biomonitoring of 30 trace elements in urine of children and adults by ICP-MS. Clin. Chim. Act 365, 310318.

HYMAN M. H., 2004. The impact of mercury on human health and the environment. Altern. Ther. 10, 70-75.

Jemal A., Graubard B. I., Devesa S. S., Flegal K. M., 2002. The association of blood lead level and cancer mortality among whites in the United States. Environ. Health Perspect. 110, 325-329.

KaBATA-PENDIAS A., 1993. Chrom, nikiel $i$ glin $w$ środowisku - problemy ekologiczne $i$ metodyczne. Wyd. PAN, Ossolineum, Wrocław-Warszawa-Kraków, Zesz. Nauk. 5.

KABATA-PENDiAS A., ŻMUDZKI J., 1992. Rtęć w środowisku - problemy ekologiczne i metodyczne. Wyd. PAN, Ossolineum, Wrocław-Warszawa-Kraków, Zesz. Nauk. 10.

KaBATA-PENDIAS A., SzTEKE B., 1994. Arsen $i$ selen $w$ środowisku - problemy ekologiczne i metodyczne. Wyd. PAN, Warszawa, Zesz. Nauk. 8.

KabATA-Pendias A., SzTeKe B., 1998. Ołów $w$ środowisku - problemy ekologiczne i metodyczne. Wyd. PAN Kom. Nauk. Czł. i Środ., Zesz. Nauk. 21.

Kabata-Pendias A., SzTeKe B., 2004. Żelazo i mangan $w$ środowisku - problemy ekologiczne i metodyczne. Wyd. PZH, Warszawa, T. 55, Supl. 239.

Kabata-Pendias A., SzTEKe B., 2012. Pierwiast$k i$ śladowe $w$ geo- $i$ biosferze. Wyd. Nauk. IUNG-PIB, Puławy.

KAPAJ S., PETERson H., LIBER K., BHATTACHARYA P., 2006. Human health effects from chronic arsenic poisoning- a review. J. Environ. Sci. Health A 41, 2399-2428.

KAZANTZIS G., 2002. Mercury exposure and early effects: an overview. Med. Lav. 93, 139-147.
KRZYWY I., KRZYWY E., PASTUSZAK-GABINOWSKA M., BRODKIEWICZ A., 2010. Lead- is there something to be affraid of? Ann. Acad. Med. Stet. $56,118-128$

KUBIAK T., 2013. Zwiazki metabolizmu żelaza $z$ rozwojem raka piersi $u$ kobiet przed $i$ po menopauzie. Przegl. Menopauz. 17, 339-342.

LOBINSKI R., MOULIN C., ORTEGA R., 2006. Imaging and speciation of trace elements in biological environment. Biochimie 88, 1591-1604.

MERIAN E., 1991. Metals and their compounds in the environment. VCH, Weinheim, New York, Basel, Cambridge.

NAVARRO SILVERA S. A., ROHAN T. E., 2007. Trace elements and cancer risk: a review of the epidemiologic evidence. Cancer Causes Control 18, 7-27.

OCIEPA-KUBICKA A., OcIEPA E., 2012. Toksyczne oddziaływanie metali ciężkich na rośliny, zwierzęta $i$ ludzi. Inż. Ochr. Środ. 15, 169180.

Pais I., Benton Jones J., 2000. The handbook of trace elements. St Lucie Press.

Plum L. M., RinK L., HAASE H., 2010. The essential toxin: impact of zinc on human health. Int. Environ. Res. Publ. Health 7, 1342-1365.

ROMANOWICZ-MAKOWSKA H., FORMA E., BRYŚ M., KRAJEWSKA W. M., SMOLARZ B., 2011. Concentration of cadmium, nickel and aluminium in female breast cancer. Pol. J. Pathol. 4, 257261.

SobańSKi L., SprZęcZKa-NiedolaZ M., ŁebeK G., 2007. Rola chromu w życiu człowieka. Bromat. Chem. Toksykol. 2, 113-119.

Stern B. R., Solioz M., Krewski D., Aggett P., Aw T., BAKER S., CRUMP K., DOURSON M., Haber L., Hertzberg R., Keen C., Meek B., RUDENKO L., SCHOENY R., Slob W., STARR T., 2007. Copper and human health: biochemistry, genetics, and strategies for modeling dose-response relationships. J. Toxicol. Environ. Health 10, 157-222.

SUSSMAN H., 1992. Iron in cancer.Pathobiology. $60,2-9$.

SZYMAŃSKA-CHABOWSKA A., ANTONOWICZ-JUCHNIEWICZ J., ANDRZEJAK R., 2004. Analiza stężen wybranych markerów neoplazmatycznych u osób zawodowo narażonych na arsen i metale ciężkie. Med. Pracy 55, 313-320.

TERPIŁOWSKA S., ZAPOROWSKA H., 2003. Chromium and its role in a prevention and therapy of some diseases. Ann. Univ. Mariae Curie-Skłodowska 58, Supl. 13, 338-342.

WilHElm M., EWERS U., ScHUlz C., 2004. Revised and new reference values for some trace elements in blood and urine for human biomonitoring in environmental medicine. Int. J. Hyg. Environ. Health 207, 69-73.

ZAHIR F., RIZWI S. J., HAQ S. K., KHAN R. H., 2005. Low dose mercury toxicityand human health. Environ. Toxicol. Pharmacol. 20, 351360

Zambelli B., Ciurli S., 2013. Nickel and human health. Met. Ions Life Sci. 13, 321-357. 
KOSMOS Vol. 68, 3, 503-512, 2019

\section{Joanna Maria DróżdŻ-Afelt, Beata Koim-Puchowska, AleKsandra Menka}

Kazimierz Wielki Uniwersity, Department of Biotechnology, 12 Księcia Józefa Poniatowskiego Str., 85-671 Bydgoszcz,

E-mail: jdrozdz@ukw.edu.pl,koimpuch@ukw.edu.pl, alex.em@ukw.edu.pl

\section{SELECTED TRACE ELEMENTS IN THE HUMAN BODY}

\section{Summary}

In scientific publications on human nutrition the definition of "trace elements" concerns these elements, which occurs in the body tissue in very small amounts, regardless of they are essential or not In other words, it will be these chemical elements, which exist in the body or they are required for proper functioning of an organism and are characterized by low concentration. In this manuscript we focused on a number of elements, which may induce disturbances in functioning of many life processes when they are in excess. We chose iron, zinc, copper, chromium, nickel, arsenic, mercury, cadmium and lead for showing the possible role of trace elements in causing diseases, including cancers.

Key words: carcinogens, chemical elements, environmental pollution, human health, trace elements 